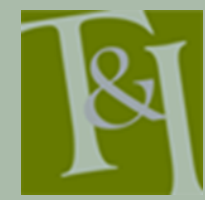

The International Journal for Translation \& Interpreting Research

trans-int.org

\title{
Listening to the voice of the translator: A description of translator's notes as paratextual elements
}

\author{
Carmen Toledano Buendía \\ University of La Laguna, Spain \\ ctoledan@ull.es
}

DOI: ti.105202.2013.a09

\begin{abstract}
Translator's notes are paratextual elements in which the translator makes his or her voice heard, thus giving up his or her invisible position in order to address the reader directly. Together with other paratextual components, translator's notes accompany the text and influence how it is read and interpreted. In the framework of descriptive and historical translation studies the analysis of translator's notes, as well as other types of paratext, may provide a privileged source of information for the contextualisation of translation processes and the reconstruction of the translation norms and policies in force at a specific moment. Furthermore, it may lead to a better understanding of the position and reception of literary translated texts. This paper shall provide a description of some of the contextual, pragmatic and functional features of translator's notes as evidence of the richness of the practices and procedures that are hidden within this type of paratext in order to reveal the often under exploited potential of such data for Descriptive Translation Studies; for illustrative purposes, examples are provided from eighteenth-century and nineteenth-century Spanish translations of English novels.
\end{abstract}

Keywords: translator's notes, paratext, literary translation, translated literature, descriptive and historical translation research

\section{Introduction}

Gerard Genette defines paratexts as 'those liminal devices and conventions, both within the book (peritext) and outside it (epitext), that mediate the book to the reader: titles, and subtitles, pseudonyms, forewords, dedications, prefaces, intertitles, notes, epilogues and afterwords' (1997, p.xviii). These literary tools are elements that surround and accompany the text, presenting the text to the public in a book format. As such, these elements play an important role in the reading and reception of a text. However, according to Genette paratextual elements are positioned in an 'undefined zone', occupying an ambiguous position both inside and outside of the text. This ambiguity makes it difficult to delimit their textual and extratextual character and to perceive of them as an integrated part of the text.

The importance of studying paratexts has not gone unnoticed within Translation Studies. For instance, translation prefaces and introductions have proven essential for the reconstruction and development of the History of Translation (Schulte and Biguenet, 1992; Vega, 1994; Delisle \& Woodsworth, 1995; Robinson, 1997). Tahir-Gürçaglar (2002) points out the relevance of this textual, extratextual and paratextual material in historical translation research, mentioning its importance in 'offering clues about a culture's definition of translation' and explaining how it provides 'a valuable insight into the production and reception of translated texts' (p.45). It is this borderline position between the inside and outside of the text that makes 
paratexts such an interesting object of study. In the framework of descriptive and historical translation studies, paratextual elements may be useful material for the contextualisation of translation processes and an understanding of the translation policies and translation norms in force at a specific moment in time. As indicated by Toury $(1995, \mathrm{p} .65)$, they can be viewed as a combination of the textual and extratextual sources of information that are needed to decipher the translation norms that underlie the target text production. Paratextual elements such as prefaces, epilogues, introductions, notes or translator's notes may sometimes turn into metadiscourses containing explicit theoretical statements about translation norms and a translator's decision-making processes. At the same time, their very existence is the result of a norm-governed decision, a norm-regulated behaviour from which norms can be inferred.

The focus of this article is on the study of translator's notes, a type of paratext specific to the practice of translation. Although research on translator's footnotes has been carried out within the discipline of Translation Studies, it has primarily focused on footnotes that are either created in a specific spatial and temporal context, or it has focused on footnotes from the literary translation tradition (Tahir-Gürçaglar, 2002; Martin, 2006; Paloposki, 2010). Several authors, including Paloposki (2010), Martin (2006) and TahirGürçaglar (2002) agree that there is a potential wealth of information to be obtained from such material:

\footnotetext{
What would be a more fascinating clue to a past translator's work than his or her footnotes, the one spot in the translation that is clearly the translator's own voice? [...] Footnotes, like footprints, are marks left behind by people who have gone their way, and they let us follow and discover the paths they have taken. (Paloposki, 2010, p.87)
}

However, despite the fact that there is explicit interest in this field of study, Paloposki (2010, p.91) brings our attention to the fact that existing research has not yet provided an overview of the general practice of the use of footnotes in translations.

This article provides a description of some of the aspects that define the contextual, pragmatic and functional nature of these paratextual elements in translation. Using Genette's outstanding contribution to the analysis of paratexts as a point of departure (1997), this article explores the richness of the practices and procedures that are hidden within translator's notes and aims to reveal the unfulfilled potential of such data for Descriptive Translation Studies.

\section{Translator's notes as a paratext}

Translator's notes are made up of explicit and direct statements. In these statements the translator's voice is clearly distinguished from the voice of the source text's author for the purpose of annotating the text. The translator uses this tool to include information he or she considers to be of interest or importance to the reader, but which, for one reason or another, cannot be included in the main text. Translator's notes make the translator's voice heard as he or she speaks directly to the reader, making the invisible translator visible to reader whilst interrupting the flow of reading.

Formally speaking, translator's notes are no different to other types of notes: they are statements of variable length which are always connected to more or less definite segments of the text and they are usually found printed at the bottom of the page or in its margins, although they can also be included 
at the end of each chapter or book. This unambiguous spatial layout contrasts with its pragmatic and functional vagueness. The variety of practices and messages that can be included in notes is as broad as the relationships that they can establish with the text they accompany, as will be seen in the examples provided. However, it is important to state that it is precisely in relation to this same text that their paratextual nature and specific characteristics need to be defined.

It quickly becomes apparent that translator's notes are probably one of the most difficult paratexts to define when trying to determine the textual or extratextual nature of notes. From a geographical perspective, the extratextual nature of translator's notes is revealed by their position in the margins of what is conventionally referred to as the main body of the text. However, it is a rather more complicated process to try to define their extratextual or textual nature by using a connective perspective. The reason for this is that the relationship between translator's notes and what could be described as the internal logic of the texts is often changeable and the lines between the two often become blurred.

Translator's notes appear to be sprinkled throughout the text, emerging and becoming visible at specific moments during the reading of the text. The translator resorts to using them at different moments and with different intentions. These intentions may range from the purely academic and explicative right through to the noticeably stylistic, or the translator may resort to their use based on moral or political motivations. Furthermore, the translator may also make use of different styles. Consequently, translator's notes may lack spatial, discursive or functional unity. This inconsistency in their nature makes it difficult to identify their textual or extratextual character, at least from a theoretical, a priori and decontextualised approach. But, at the same time, it is this very variability that makes them such a revealing source of information for the historical and descriptive analysis of translated texts. By observing the presence (or absence) of notes, i.e. when, how and what they are used for, it is possible to obtain very useful data on the existing concept of translation, the position of literary translation in the target system and the translation policy and norms, both explicit or implicit, in force in a specific historical and/or professional context. In addition, it is also possible to obtain data on the reception process of a translation (Toledano Buendía, 2001a).

The aim of this article is not to reach a general characterisation of translator's notes, but instead to reveal certain aspects of these paratexts that, if analysed further, would prove enlightening for the study a specific translation epistemological cut or literary system. This article focuses on the description of the spatial-temporal status of translator's notes, their sender and addressee, and finally their function. It should be noted that these features are defined in relation to the translated text, the text that the translator's notes accompany. As already mentioned, the reason for this is that they acquire their condition of paratexts not in relation to the source text, but rather in relation to the translation. In other words, we are talking about footnotes in and of the translated text and not in the source text, even though in many cases they may make reference to it. Only with the former, and not the latter, is it possible for certain relationships to be established that influence the reception of the text, its reading, and its interpretation in the target system. 


\section{Place and time of translator's notes}

Genette makes a distinction between peritexts and epitexts. This is a distinction that derives from the physical location of paratexts in relation to the main text. According to Genette, peritexts are those elements located in the text, i.e. the title or a preface; epitexts are those elements located off the text or outside the book, i.e. interviews, reviews, etc. (1997, p.5). Translator's footnotes belong to the spatial category of peritexts. They are usually placed either at the bottom of the page or in the margins, although they can also be found appended at the end of the text, especially when the translator is also the editor of the same work. In literary translations, it has been observed that there is a tendency to use endnotes in translations of poetry and plays, whereas there is a tendency to use footnotes in the translation of prose works. Translator's notes, like other types of notes, are normally flagged by a superscripted number, letter or symbol immediately following that part of the text being referred to in the note.

The spatial simultaneity of translator's notes with the main text, however, does not necessarily imply chronological simultaneity. The temporal features are defined using the time at which the notes appear in relation to the text they refer to. Taking the publication date of the main text they accompany as a point of reference, Genette makes a distinction between prior, original and later paratexts $(1997$, p.5). For translator's notes it is possible to appear before, at the same time as, or later than the main text. Those elements that were originally in the source text and which have been translated, e.g. a title or a dedication, are translated paratexts and are therefore catalogued as prior paratexts. Those paratexutal elements which appear simultaneously with the translated text, e.g. the editor's preface to the translation edition or the translator's notes, are catalogued as original paratexts. Both prior and original paratexts introduce the translation into the new reception context, present it to its readers and determine its position, reading and interpretation in the target cultural system.

Generally speaking, translator's footnotes are original paratexts as they are typically published at the same time as the translated text they accompany. However, it is possible to find examples of previous translator's notes, especially in second-hand or indirect translations. For example, fifty out of the ninety-eight translator's notes found in the Spanish translation of the novel Robinson Crusoe by Daniel Defoe, published in 1849-50, were inherited by the Spanish translator D. José Alegret de Mesa, having originally come from the earlier French translation. Therefore, in this case these notes are considered to be previous peritexts.

In other cases, translator's notes may suffer certain quantitative or qualitative modifications over the course of later editions, including: an increase or decrease in the number of notes, the removal of notes, or alterations to the original message. If the translator's notes - or any other paratextual element - are modified in later editions, these notes are categorised as later peritexts. One of the main reasons for modifying translator's notes is to ensure the translation is suitably adapted to a given reception context. The new cultural and communicative situation in which the text is embedded may require the translator to provide information that adapts the text to the target receivers' expectations and needs. In the aforementioned translation of Robinson Crusoe, for instance, the notes added by the Spanish translator seem to be aimed at adapting the text to the new implicit knowledge of the readers it was addressed to. The translator increases the number of definitions and explanations for terms and expressions because of the presupposition that the young readers the novel is addressed to may not 
understand certain elements such as sailing terms and expressions ('rastras', 'tirar las rastras', 1849, p.19), or units of measurement or currencies ('guineas', 'por un viaje a guineas', 1849, p.13) ${ }^{1}$.

Translator's notes can also be altered in later editions as a result of deceptive practices within the publishing industry. In the history of publishing, it is not uncommon to find modified versions of translations being passed off as entirely new versions, with or without the translator's permission. This seems to be the case with the anonymous Spanish translation of Robinson Crusoe, which was published in 1885 by Imprenta de la Correspondencia. Although they announced it as being the first Spanish translation to have been produced directly from the original English novel all the previous translations were indirect translations from French versions (Toledano Buendía, 2001b) - it was actually a reprint of the aforementioned translation by D. Alegret de Mesa that had been published in 1849-50. In this case, the spelling had been updated and the notes of the French translator removed, but the translated text was the same.

\section{Sender and addressee of translator's notes}

\subsection{The sender of translator's notes}

At first glance, defining the sender of translator's notes appears to be a rather straightforward process: the sender of the translator's notes is the translator of the text. However, Genette (1997, pp.8-9) makes the distinction between two types of senders, and thus distinguishes between two types of paratexts: authorial paratexts and allographic paratexts. The former are those produced by the author of the text, whilst the latter are produced by a third person. This third party is an individual who obtains the authority to be the putative father of the new text when the author of the text transfers part of his or her authorial responsibility to them, i.e. a second editor, an anthologiser, or equally, a translator. As such, translator's notes belong to the category of allographic notes in as far as they are messages sent by a third person who has been delegated part of the responsibility for the text, and who has thus been given a space to have his or her voice heard (Genette, 1997, p.322). This categorisation of translator's notes underlies the assumption that translations are derivative in nature, always dependent on the source text and the secondary status of translators.

However, it should be remembered that translations are texts that are embedded in a different communicative situation, one that results from a rewriting exercise aimed at fulfilling different necessities to those that determined the creation of the source text in its context. Historically, there have been times when the translated text has become independent from its source text to such an extent that it even exceeds the original. This may be due to the performance of a totally different function in the target system, the translator's prestige, or simply its literary fame. Readers sometimes expressly choose to read the translation of a literary work made by a specific translator, such as Jorge Luís Borges's Orlando or Vladimir Nabokov's Eugenio Oneguin. In such cases, the translator acquires the status of author, losing his

\footnotetext{
1. The incorporation of Daniel Defoe's Robinson Crusoe (1719) in Spanish literature is characterised by its late appearance and its reception as a piece of children's literature. The first translation was published in Spain in 1826 - more than 100 years after it was originally written - in an abridged version for children (Toledano Buendía, 2001b).
} 
or her inferior character in the same way as a conductor or an actor does when we refer to Karajan's Mahler 9 or María Callas's Norma. The (re)interpretation of the text involved in the translation process gains the same or more value in the target system than the creation of the source text, which in one way or another is also a recreation of other texts. This perspective would endow the translator with the status of author and consequently the translator's notes in such a case would carry the label of authorial paratexts. It can be stated, then, that the task of cataloguing translator's notes as either authorial or allographic paratexts is affected by the status bestowed on the translator and the translated text.

\subsection{The addressee of translator's notes}

Along with the sender, another feature that defines the pragmatic nature of paratextual elements is the addressee. In the case of translator's notes, the addressees are all the potential readers of the translation, which is to say its primary readers. It is worth clarifying here that these primary readers are addressees with regards to the translated text and not the original text. The target text receiver is considered a fundamental component of the translation process and a decisive factor in the translator's decision-making process and the resulting product. Target text receivers are members of another cultural and linguistic community whose expectations and necessities regarding the text are different to those of the source text's receivers, as is their knowledge base and their presuppositions reception parameters. It is the target text's implicit reader that the translator's notes are addressed to, which makes them a determining factor in the presence, use and message of this paratextual material.

It should not be forgotten that most of these paratext messages possess a specialised character and, as a result of this, may not be seen as indispensable for the purpose of approaching the text despite the visibility of the position they occupy; the reader always has the power to choose whether to read them or not:

\footnotetext{
We must observe that notes [...] may be statutorily optional for the reader and may consequently be addressed only to certain readers: to those who will be interested in one or another supplementary or digressive consideration, the incidental nature of which justifies its being bumped, precisely, into a note. (Genette, 1997, p.324)
}

Furthermore, not all readers have the same capacity to form opinions about a work, let alone to censor or forbid it. One can easily imagine then that, quite often, the translator also addresses his/her notes to another type of reader - a reader whose opinion and interpretation is decisive for the reception and incorporation of the text in the target literary system. These are powerful agents in matters of diffusion, circulation, critical evaluation or translation of literary works, whose judgments determine the acceptance or rejection, placement and replacement of the text in the target system and the interpretation of the works. This is the very idea being referred to by Lefevere's concept of patronage (1992). Patronage functions as a type of external control mechanism as it operates outside the literary system, 'something like the powers (persons, institutions) that can further or hinder the reading, writing, and rewriting of literature' (Lefevere, 1992, p.15). Not only are they authorities that favour or hinder the circulation of the text, but they also filter and determine the specific way the work is received in the target culture. They influence the actions of the writers and rewriters who create, describe, translate and spread literary works in accordance with the prevailing poetics and ideology of the time, which is to say 'the dominant 
concept of what literature should (be allowed to) be' and 'what society should (be allowed to) be' (Lefevere, 1992, p.14). According to Iris Zavala's terms ${ }^{2}$, these influential or 'privileged' readers mould, to a greater or lesser extent, the textual dialogue depending on the power relationships in operation and their degree of flexibility.

At the time of writing some of his notes, the eye and opinion of the privileged reader seems to be present in the mind of the anonymous Spanish translator of the Samuel Richardson novel Pamela Andrews, ó la virtud recompensada, which was published in 1799 from the French version by Abbé Prévost, dated 1741. For example, when suicide crosses Pamela's mind because of the desperate situation in which she finds herself - an idea that Pamela herself regrets and is ashamed of - the translator reacts by including a reproving note. This decision leads us to question his didactic intention as well as his wish to anticipate and prevent the possible intervention of the Inquisition's censors at that time:

Todas las reflexiones que hace aquí Mr. Richardson en boca de Pamela son muy á propósito para contener á los mortales desesperados del abominable crímen del suicidio, tan contrario a la órden de Dios, que la misma naturaleza le detesta y aborrece. Y como en Inglaterra es mas comun este pecado que en ninguna otra parte del mundo (sea efecto de aquel clima, ó mas bien de la demasiada corrupcion de las costumbres inglesas, como lo dice el célebre Young cap. del Suicidio), por eso carga la mano Richardson contra tan mostruosa accion, y hace ver que solo con la gracia de Dios y los auxilios de la Religion es capaz el hombre infeliz de resistir á las desgracias de esta vida con la esperanza consoladora, que le da el christianismo, de pasar á otra mejor, despues de llevar con paciencia los trabajos que la Providencia le envia para su mejor bien. (1799, vol II, pp.102-3)

All the thoughts that Mr Robinson puts in Pamela's mouth have the aim of keeping those despairing mortals from committing this abominable crime, which is against nature, against God's will. As in England this sin is much more widespread than anywhere else (either due to its climate or to the corruption of English customs or morals, as the famous Young says in the chapter about Suicide), Richardson attacks this crime and points out that only with God's grace and the Christian comforting hope of going to a better life, having patiently accepted the travails that Providence sends, will an unhappy man be able to bear the misfortunes of this life. ${ }^{4}$

The translator appears to consider it more educational to include the episode, despite it being contrary to the religious or ideological values of the time, and to refute it - hence avoiding censorship - rather than omit it entirely. He lectures and sermonises the reader about this abominable crime and explains the didactic reasons that have led Richardson to include this episode. The voice and presence of a mediator has a correcting effect much more effective than the omission of the transgressor element because this gives the translator the chance or opportunity to enlighten. In this case, the translator not only anticipated the censor's reaction and took preventive measures, but he or she

\footnotetext{
${ }^{2}$ Iris M. Zavala, in her study on Spanish eighteenth-century narrative discourse, created the figure of the 'privileged reader' to refer to 'another group of readers who mediate and interrupt the dialogue between the sender and addressee' (1987, p.15); this is a figure which establishes the normative authorial discourse and therefore restricting the reading possibilities through the position of power they hold.

${ }^{3}$ Original old spelling is retained in all the examples of Spanish translator's notes.

${ }^{4}$ The translation of the Spanish translator's notes into English is my own.
} 
also adapted the novel to the educative function that fiction was supposed to fulfil during that particular period. This note, and similar notes that accompany this translation, make it possible for a more general normative framework to be constructed. This framework sits above the translation norms and it is made up of ideological and poetic norms. The translator follows these ideological and poetic norms to try to adapt the text to the expectations of all readers, especially the privileged reader, and thus ensure its inclusion in the target literary system.

\section{Functional status of translator's notes}

The function of a paratext is defined by the relationship that it bears to the text it accompanies.

The paratext in all its forms is a discourse that is fundamentally heteronomous, auxiliary, and dedicated to the service of something other than itself that constitutes its raison d'etre. This something is the text (Genette, 1997, p.12).

As a result of this derivative and variable character, its functional status cannot be defined theoretically a priori, instead it needs to be stated individually and contextualised.

In the case of translator's notes, it is interesting to observe the wide range of subordination levels that can be established between the paratextual messages and what the translator perceives as the internal logic of the text. Functional regularities can be induced, but they cannot be considered a universal rule and it is not possible to extrapolate their specific epistemological break further. The translator's decisions are governed by factors such as the expectations of the translation's addressee, the purpose of the text, its genre or the activities of the publishing company. The presence (or absence) of notes as well as their use and function are not totally the result of the translator's individual and free choice, instead it is in part dictated a priori to the translator by translation policy and norms. For instance, using footnotes to supply additional information on culturally bound terms might be expected in critical editions of canonical literature that are being published by prestigious publishing houses, but never in children's literature. Obviously, these general norms and guidelines are neither static nor absolute; they change over time and vary between cultures and genres.

Despite this, translator's notes are also the result of an interpretation exercise carried out by the translator, one that is conditioned by ideological, cultural and political factors. The dynamics of the act of translating is reflected in the demands that the text makes upon the translator's awareness and experience and also in the translation decision-making process. The translator participates in the reconstruction of the text by projecting his/her own private associations, which in turn influences his/her textual decisions. Therefore, within general guidelines set by the reception context, the translator is free to choose when and where to intervene; he or she tends to complete the text, fill in gaps or supply details and includes responses to what are considered appropriate points. The translator must know what the rational thing to do is in a specific context and with a specific goal and within the particular circumstances surrounding the production and reception of the text. These circumstances will depend on several factors, such as the cultural distance between the source text and the target text, the requirements of the target text potential reader, the type of text, the expected degree of translator's visibility, ideology, the context, etc. What is identified as a problem in a specific pair of texts (source text and target text) will not 
necessarily present itself as one between other pairs (the same source text and another target text). This happens not only with translations of the same source text at different times, which is the result of language undergoing constant changes, but even with translations from the same period of time, function and intended reader. From this perspective one could state that the translator's notes are also, to a certain extent, idiosyncratic; that is, the result of a translator's decision towards one solution rather than another within the limits fixed by norms, and of a previous selection of linguistic material.

In order to summarise the diversity of practices found under the translator's notes into basic and recurrent procedures, two main functional types have been distinguished. On one hand, there are those translator's notes that function as a supplement to the text and have an explicative and informative function, and on the other hand, there are those which act as a commentary and have a discursive or performative function.

\subsection{Explanatory notes: Notes as a supplement}

The main function of explanatory notes is to provide additional information that is considered necessary in order to achieve a perfect understanding of the source text and to reproduce all the effects of the original text in the target language. To a certain extent, they do not add anything that was not implicit in the source text and that was not presupposed to be known by the source text reader. They seek to compensate for the information lost in the process of text transfer from source language and source communicative situation to the target text. The translator's aspiration is to bring the target reader closer to the source text and to its reception context by providing philological

clarifications, historical descriptions, cultural explanations, etc. In many cases these notes barely detach the reader from the story, so much so that many of these notes could be included in the text simply by making use of commas, dashes or parentheses. In an eighteenth-century Spanish translation of Henry Fielding novel's Tom Jones, for instance, when Hamlet's Prince of Denmark is mentioned, the Spanish translator adds in a note: 'Tragedia de Shakespeare' (1796, vol.iv, p.42); or when Tom Jones is driven to Newgate, the translator specifies 'Prision de Lóndres' (p.97).

In these notes translators call attention upon problems of linguistic or cultural equivalence and the loss of certain meaning components that the discrepancy between the source and target text communicative situations bring about. In order to solve them, verifiable and objective information is usually conveyed. Often these are presented as explicit statements of Toury's operational norms, of direct actual decisions made during the translation process $(1995$, p.58). This may consist of philological clarifications or explanations of cultural or historical aspects. For example, in a Spanish translation of Chaucer's The Canterbury Tales the translator explains the meaning of 'love-dayes':

Días de tregua, durante los cuales intervenían las autoridades eclesiásticas. Lit.: love-dayes, días de amor o amistad, a propósito para hacer las paces. (Chaucer, Los Cuentos de Cantorbery, 1921, p.10)

Days of truce, during which the ecclesiastical authorities intervened. Lit.: Love-dayes, days of love or friendship, in order to make up.

He also provides detailed information about the drinking trough of Saint Thomas, which appeared to be a well-known place at the time: 
A dos millas de Londres, en el camino de Cantorbery, donde solían tomar algun descanso los peregrinos, mientras bebían las caballerías'. (1921, p.29)

Two miles from London, on the road to Canterbury, where the pilgrims used to have a rest while the horses drank some water.

These notes usually have an erudite tone. Indications of literary sources, intertextual references or quotations can also be found in these notes. When Almagest is mentioned the translator specifies: 'El Almagesto, Libro de astronomía, de Tolomeo, ${ }^{, 5}$ (1921, p.134).

Translators may also give details, specify something vaguely recalled in the text, or clarify aspects that may be obscure for the target text reader. This can be seen in this note taken from the first Spanish translation of Henry Fielding's Tom Jones (1726) when the translator explains the reference of this following sentence in the Spanish text:

...que tengo hechos pedazos mil vidrios en que estaban escritos versos llenos de este famoso epiteto.

...got a thousand broken pieces of glass where verses full of this epithet were written.

As follows:

Esto hace alusión á la costumbre que hay en Inglaterra de escribir en las vidrieras con los diamantes de sortijas, nombres, versos, sentencias y otras cosas. (1726, vol. iv, p.135)

This refers to the custom in England of writing names, verses, sentences and other things on glass using diamond rings.

Although the source text author certainly cannot be responsible for the messages contained in the translators' notes, one could state that in some cases the explanatory notes add information that the source text author would have liked the target reader to possess in order to fully comprehend the text, and that the author would have probably added if he or she had anticipated the prospective reception contexts of his/her work. The translator makes him or herself visible in order to bring the reader closer to the original text via a foreignising approach, the result of which is a source-text-oriented translation.

\subsection{Discursive notes: notes as commentary}

There is another category of notes, the function of which is not to provide the implicit reader with objective information or details, or at least not exclusively. Compare the following two notes:

Obsérvese que á los ministros de la comunion protestante les es permitido contraer matrimonio. (Nota del T.E.) (Robinson Crusoe, 1849-50, vol. ii, p. 138)

Please note that ministers of the protestant communion are allowed to get married. (Note by Spanish Translator)

\footnotetext{
${ }^{5}$ Book of astronomy by Ptolomeo.
} 
Los ministros de la Iglesia anglicana, como protestantes, se casan, y así no es extraño que Alworthy, como Señor de la parroquia, tuviese estas miras, en atencion á las buenas prendas que creia en Jenny. (Tom Jones, 1726, vol i, p.21)

Ministers of the Anglican parish church, such as Protestants, get married, and therefore it is no surprise that Alworthy, as a member of the church would have these intentions, regarding the good gifts he saw in Jenny.

In these notes, both translators mean to inform the target reader that celibacy is not a requirement for Anglican priests and therefore that they are allowed to get married. But simultaneously they are also seeking to avoid a misinterpretation of a practice forbidden by the Catholic religion and to reinforce a 'normative' reading of the text. While the translator of Robinson Crusoe does it implicitly and he merely furnishes that information neutrally, Tom Jones's translator guides the interpretation of the story and justifies Alworthy's behaviour. He has an obvious disposition to overtly interfere with the logical unravelling of the internal logic of fiction and to provide keys for reading and interpreting the target text.

The main characteristic of discursive notes is that the translator does not only 'say something', but also comments on something and expresses an opinion about it, that is to say, 'do something'. It is their illocutionary force that creates this difference between saying and doing; the communicative intention of theses paratextual messages is not restricted to providing verifiable information as they also express a particular judgement and/or attitude. In using these notes, the translator is purposefully guiding the interpretation of the text and accords it with a socially acceptable meaning.

In the following example, the anonymous translator of Tom Jones foresees the possibility of what apparently seems to be a case of incest concerning the main character. This could be scandalous so the translator decides to interfere in order to prevent censorship and the disapproval of the reader. In order to do so, he does not hesitate to uncover the intrigue, pretending that he has not done so by asking the reader to disregard what he has said.

\begin{abstract}
Se suplica al lector que suspenda el juicio, á pesar de todas las apariencias que encontrará de ser cierta esta especie; porque ¿quién sabe lo que puede venir todavía? Por otra parte, somos tan zelosos de su gusto que no queremos privarle del de la sorpresa, adelantándole la solucion de este enigma. (Tom Jones, 1796 vol. iv, p.183)

The reader is asked to suspend his judgment regardless of all appearances that can be found and may verify this idea; because who knows what lies ahead? On the other hand, we are so jealous of his delight that we do not want to deprive him of the surprise by disclosing the solution of the enigma.
\end{abstract}

In the following example taken from a twentieth-century Spanish translation of Moll Flanders, in which Moll makes a deal with someone who owes her money, the translator, Carlos Pujol, explains:

Es decir, que salda la imaginaria deuda cobrando una cuarta parte del dinero cinco chelines por libra, o sea, ciento cincuenta libras más diez en concepto de intereses, recibiendo cien en oro y las otras sesenta en géneros. Obsérvese siempre el minucioso verismo de todos estos detalles referentes a cuestiones monetarias. Moll cuando miente, aun tratándose de un asunto de poca importancia, cuida los detalles hasta lograr verdaderas obras de arte de la mentira. (Moll Flanders, 1981, p.95) 
That is, the imaginary debt is repaid by taking a fourth of the money -five shillings to the pound-, therefore, one hundred and fifty pounds -plus another ten on interest-, receiving one hundred in gold and the other sixty in goods. Take note of the meticulous realism of all these details regarding money. When Moll lies, even though the matter is of little importance, she is so careful with the details that her lies become works of art.

Correcting elements are introduced in the text and mediating 'instances' slide into the text, guiding and restoring what is viewed a normative interpretation and reception of the text. These instances separate reading from interpretation and interrupt the dialogue between the author and the reader. The visibility the translator achieves through this contact with his or her public makes it clear that the translator has become the principle story 'teller'. The effect this has it to visibly elevate the translator above the voice of the narrator as elements that guide the reading of the text are added; in many cases, these elements have the effect of normalising the reading process. In extreme cases, these notes become true digressions that not only do not favour the normal discursive flow of the original author, but also break it by taking into consideration subject matters that hold no relationship whatsoever with the topic of the story. In order to illustrate this particular point, consider the following example which is taken from the Spanish translation of the fourth part of Gulliver's Travels, 'A Voyage to the Country of the Houyhnhnms'; in Gulliver's sarcastic account of English aristocracy, the translator, no doubt afraid to favour the revolutionary credo, wrote:

No creo que Lector ninguno tome á la letra esta mordaz hipérbole. La Nobleza Inglesa, segun M. de S. Euremond, posee la quinta esencia de la civilidad, y puede decirse en general que los caballeros Ingleses son lo mas finos de la Europa. Apénas habrá alguno que no tenga su espíritu bien adornado. Aprecian mucho á los literatos, cultivan las ciencias, y es muy raro el que no se halla capaz de componer un libro. No se debe, pues, tomar á la letra este pasage sino como un simple pasatiempo; y lo mismo digo de qualquier otro rasgo de sátira que aquí se encuentre. Si alguno ménos sencillo estuviese de humor aplícárselo seriamente á la Nobleza Francesa, la haria una injusticia mucho mayor. Estos rasgos no pueden mirar á otros que á aquellos hombres que se eleváron del polvo, ó por sus padres ó por ellos mismos; mas en ningun caso á las personas de calidad, que tanto en Francia como en otras partes son la porcion mas virtuosa, mas comedida y mas civilizada de la República. (1800, vol. iii, p.165)

I do not believe that any reader would consider following this caustic hyperbole to the letter. According to M. of S. Euremond, English nobility possesses the fifth essence of civility and it could be said that English gentlemen are generally the finest of Europe. Hardly any of them lack a good-natured spirit. They highly appreciate writers, they cultivate knowledge, and it is very rare to come across one who is unable to compose a book. Therefore, this passage should not be followed to the letter, but as a simple pastime; this also includes any other satirical reference that may be found here. If a more modest man were so humoured to seriously apply it to French Nobility, he would be paying a much greater injustice. These aspects can only belong to those men who arose from dust, either due to their parents or themselves; but under no circumstance to quality people that in France as well as in other places are the most virtuous, most obliging and most civilized of the Republic.

The quantity of discursive notes and the tolerated degree of digressions varies depending on the period, the reading public, the genre, and the politics and 
translation norms in force. Currently, examples of this functional category in contemporary Spanish literary translations are very limited, but if we look back through history we see that it reached its height in the Spanish translations of novels during the $18^{\text {th }}$ and $19^{\text {th }}$ century. As such, most of the examples in this article have been extracted from this period of time. During this historical period, prose writing was supposed to play an educative role and provide moral guidance. Consequently, its form and content were restricted by existing poetic norms and moral values that existed to fulfil the religious, moral and political doctrines of the Christian church and the Monarchy being enforced by the Inquisition censors in charge of supervising such texts (Toledano Buendía, 2001c, 2004). The visibility of the translator often highlights the translation policy that perpetuated the moral, aesthetic and ideological values that were in force in Spain at a given moment through the domestication or exoticising a stereotyped image of the other.

In all of these cases, notes are characterised by their discursive nature, which bursts into the disclosure of the internal logic of fiction when recalls are introduced. While it is true that all notes interfere in the text, explanatory notes set out a minimal bifurcation in order to favour the main flow, whereas the latter abruptly take the reader to another order of reality. In these notes the translator gains visibility, explicitly showing that translating always reflects a certain ideology and poetics and that it manipulates the text so that it functions in a given society; as such, these notes serve as a vehicle for the confrontation of other views and ideologies within the text itself, for the dialogue between the source and target culture, and for the source author and the translator.

\section{Conclusion}

Translator's notes are paratextual elements of a varied nature. They clearly illustrate the borderline nature of these elements - located both in the text and off text - as mentioned by Genette. Certain types, such as discursive notes, clearly hold paratextual positions. In fact, they may even go so far from the text that they become peritextual appendices that are considered autonomous digressions close to critical metatexts. On the other hand, there are other notes, such as explanatory ones, that hardly cause more than a slight deviation from the text. In fact, these types of notes could easily form part of the text with the addition of parenthesis or dashes. However, both types of notes accompany the text and determine its reading, interpretation and reception in the target system. As demonstrated, it is possible to find a great variety of practices and messages encompassed under the term translator's notes. This fact serves to highlight their dynamic and contextual nature. However, it is the use the translator makes of them as well as the function they carry out in the text that can be used to reveal information about the position and reception of the text in a specific literary system, including: the relationship of the translator with the text; the degree of visibility of the translator and the text; and also the norms and translation trends in force at a specific moment in time. Above all, these paratexts serve to highlight that it would be impossible to perceive the translation process as merely the innocent transfer of content which is circumscribed to the text; the belief that there may exist a single idealised form of objective correspondence is one that is shattered by the visibility of the translator: translator's notes are the footprints of a rewriting process that affects the source text and the conditions that govern them. This is why the study of translator's notes is so relevant within the framework of both historical and descriptive translation studies. 


\section{References}

Chaucer, G. (1921). Los Cuentos de Cantorbery. Traducción y notas de Manuel Pérez y del Río-Cosa. Madrid: Editorial Reus.

Defoe, D. (1849-1850). Aventuras de Robinson Crusoe. Traducción de Don José Alegret Mesa. Madrid: Don Nicolás Cabello.

Defoe, D. (1885). Robinson Crusoe. Traducidas al castellano del original inglés. Madrid: Imprenta de la Correspondencia de España.

Defoe, D. (1981). Moll Flanders. Traducción de Carlos Pujol. Barcelona: Planeta.

Delisle, J., \& Woodsworth. J. (Eds.). (1995). Translators through History. Amsterdam: John Benjamins.

Fielding, H. (1796). Tom Jones ó el Expósito. Traducida del francés por Don Ignacio de Ordejon. Madrid: Imprenta de Don Benito Cano.

Genette, G. (1997). Paratexts: Thresholds on Interpretation. Cambridge: CUP.

Lefevere, A. (1992). Translation, Rewriting and the Manipulation of Literary Fame. London: Routledge.

Martin, A. E. (2006). Annotation and Authority: Georg Forster's Footnotes to the Nachrichten von den Pelew-Inseln (1789). Translation and Literature, (15), 177-201.

Paloposki, O. (2010). The Translator's Footprints. In T. Kinnunen and K. Koskinen (Eds.). Translators' Agency (pp. 86-107). Tampere: Tampere University Press 2010.

Richardson, S. (1799). Pamela Andrews ó la virtud premiada. Madrid: Imprenta Real.

Robinson, D. (1997). Western Translation Theories from Herodotus to Nietzsche. Manchester: St. Jerome Publishing.

Schulte, R., \& Biguenet. J. (Eds.). (1992). Theories of Translation. An Anthology of Essays from Dryden to Derrida. Chicago: The University of Chicago Press

Swift, J. (1800). Viages del Capitan Lemuel Gulliver á diversos paises remotos. Traducción de Don Ramón Máximo Spartal. Imprenta de Plasencia.

Tahir-Gürçaglar, S. (2002). The Use of Paratexts in Translation Research. In T. Hermans (Ed.), Crosscultural Transgressions (pp. 44-60). Manchester: St. Jerome P.C.

Toledano Buendía, C. (2001a). Usos de las notas del traductor. In M. Falces et alt. (Eds.), Actas del $24^{\circ}$ Congreso de Aedean. Universidad de Granada.

Toledano Buendía, C. (2001b). Robinson Crusoe naufraga en tierras españolas. Babel, 47, 35-48.

Toledano Buendía, C. (2001c). Apuntes sobre la traducción de la novela inglesa del siglo XVIII en España. In M. Brito and J. I. Oliva (Eds.), Polifonías textuales: ensayos in honorem María del Carmen Fernández (pp. 177-196). La Laguna: RCEI Ediciones.

Toledano Buendía, C. (2004). Evasive Devices in Literary Translation. En M. Brito (Ed), Traditions and Innovations: Celebrating 40 Years of English Studies in ULL (pp. 371-379). La Laguna: RCEI Ediciones.

Toury, G. (1995). Descriptive Translation Studies and Beyond. Amsterdam, Philadelphia: John Benjamins.

Vega, M. A. (Ed.). (1994). Textos clásicos de teoría de la traducción, Madrid: Cátedra.

Zavala, I. M. (1987). Lecturas y lectores del discurso narrativo dieciochesco. Amsterdam: Rodopi.

\footnotetext{
* This paper is a version based on an article published on R. Rabadán, T. Guzmán, M. Fernández (Eds.) Lengua y Recepción: en honor de Julio César Santoyo, 2010. León: Servicio de Publicaciones de la Universidad de León.
} 